\title{
Arsenic oral bioavailability in soils, housedust, and food: implications for human health
}

\author{
L.Q. $\mathrm{Ma}^{1,2}$, H.B. $\mathrm{Li}^{3}$, D. Zhao ${ }^{3}$ \& A.L. Juhasz ${ }^{4}$ \\ ${ }^{1}$ Research Center for Soil Contamination and Environment Remediation, Southwest Forestry University, \\ Kunming, P.R. China \\ ${ }^{2}$ Soil and Water Sciences Department, University of Florida, Gainesville, FL, USA \\ ${ }^{3}$ State Key Laboratory of Pollution Control and Resource Reuse, School of the Environment, Nanjing University, \\ Nanjing, P.R. China \\ ${ }^{4}$ Centre for Environmental Risk Assessment and Remediation, University of South Australia, Mawson Lakes, SA, \\ Australia
}

\begin{abstract}
Incidental ingestion of As-contaminated soils and housedust is an important non-dietary As exposure contributor for children living nearby contaminated sites, while consumption of rice has been recognized as the most important dietary contributor. However, to accurately assess the health risk associated with soil and dust ingestion and rice consumption, determination of total concentration and oral bioavailability of As are both important. However, compared to soils, assessment of As relative bioavailability (RBA) in housedust and rice is limited. In addition, the suitability of in vitro bioaccessibility assays to predict As bioavailability has not been compared between different exposure scenarios. Recently, by combining in vivo mouse bioassay and in vitro bioaccessibility assays, we measured As-RBA (relative to the absorption of sodium arsenate) in samples of contaminated soils, slightly-contaminated housedust, co-contaminated housedust, and rice. Results showed that As-RBA in these media showed significant variation among individual samples, suggesting the need to incorporate bioavailability to accurately assess the associated health risk. In addition, by establishing in vivo-in vitro correlations, the most suitable in vitro assay to predict As-RBA varied with the target media, suggesting the need of developing specific methodologies to predict As-RBA in different environmental media.
\end{abstract}

\section{INTRODUCTION}

Arsenic (As) is a ubiquitous contaminant present in food and the environment. Chronic exposure to As causes various adverse health effects including cancers, skin disorders, vascular disease, and diabetes mellitus (Hinwood et al., 2003). Humans are exposed to As via both dietary and non-dietary pathways, with incidental ingestion of contaminated soils and housedust being important non-dietary contributor, while rice consumption is recognized as an important dietary contributor to inorganic As intake (Juhasz, et al., 2006; Li et al., 2011, 2014, 2017; Ruby et al., 1999; Williams et al., 2009). Reliable assessment of human health risk from both the dietary and non-dietary pathways depends not only on total As concentration in soils, housedust, and rice, but also its bioavailability ( $\mathrm{Li}$ et al., 2016a; Liao et al., 2005; Ruby \& Lowney, 2012; Zhu et al., 2008; Zhu et al., 2013).

While studies have utilized in vivo animal bioassays to determine As relative bioavailability (RBA, relative to the absorption of sodium arsenate) in contaminated soils, limited researches have focused on housedust and rice (Ollson et al., 2017;
Torres-Escribano et al., 2008; Williams et al., 2009). Compared to animal models, bioaccessibility methods offer a simple, inexpensive way to estimate As-RBA. However, it is important to establish the relationship between As bioaccessibility and As relative bioavailability (RBA) so the assay is valid to predict As-RBA in soils, housedust, and food (Li et al., 2016b).

\section{METHODS/EXPERIMENTAL}

\subsection{Arsenic RBA and bioaccessibility in contaminated soils}

Twelve As-contaminated soils (22.2 to $4172 \mathrm{mg}$ As $\mathrm{kg}^{-1}$ ) were collected from typical mining/smelting contaminated sites across China. As-RBA was assessed using in vivo mouse blood AUC (area under the blood As time curve over 48-h period) bioassay following a single dust gavage dose, while As bioaccessibility was measured using five in vitro assays (UBM, SBRC, IVG, DIN, and PBET). Linear correlation between As-RBA and As bioaccessibility was established to investigate the As-RBA prediction ability of in vitro assays. 


\subsection{Arsenic RBA and bioaccessibility in housedust}

As-RBA in 12 housedust samples across China slightly contaminated with As contamination (7-38 $\mathrm{m} \mathrm{kg}^{-1}$ ) was measured using an in vivo mouse blood AUC model and compared to As bioaccessibility determined using 4 in vitro bioaccessibility assays (SBRC, IVG, DIN, and PBET).

In addition, 15 housedust samples co-contaminated with As (43-2380 $\left.\mathrm{mg} \mathrm{kg}^{-1}\right), \mathrm{Cd}\left(8.46-329 \mathrm{mg} \mathrm{kg}^{-1}\right)$, and $\mathrm{Pb}\left(127-15486 \mathrm{mg} \mathrm{kg}^{-1}\right)$ collected from $\mathrm{Pb}-\mathrm{Zn}$ ore mining/smelting sites at Hunan, China were assessed for As-, Cd-, and Pb-RBA using an in vivo mouse bioassay with metal(loid) accumulation in liver and kidneys as the biomarker of dust-amended diet consumption over a 10-d period. Arsenic bioaccessibility was assessed using 3 bioaccessibility assays (SBRC, PBET, and UBM).

\subsection{Arsenic $R B A$ in rice}

A mouse model based on steady state As urinary excretion (SSUE) was developed to determine As-RBA in rice to refine inorganic As exposure in humans ( $\mathrm{Li}$ et al., 2011). Fifty-five rice samples from 15 provinces in China were analyzed for total As, with 11 cooked for As speciation and bioavailability assessment using A mouse bioassay.

\section{RESULTS AND DISCUSSION}

\subsection{Correlation between As-RBA and bioaccessibility for contaminated soils}

Arsenic RBA in the 12 soils ranged from $6.38 \pm 2.80 \%$ to $73.1 \pm 17.7 \%$ with soils containing higher free Fe contents showing lower values (Li et al., 2016). Arsenic bioaccessibility varied within and between in vitro assays. All in vitro assays show strong linear correlation with As-RBA data $\left(\mathrm{R}^{2}=0.50-0.83\right)$, with the IVG assay providing the best estimate of As-RBA $\left(\mathrm{R}^{2}=0.81-0.83\right)$ although the IVIVC slope did not meet the criteria of $0.8-1.2$ (Fig. 1). This suggests that the IVG assay has the potential to predict As-RBA in contaminated soils from China.

\subsection{Correlation between As-RBA and bioaccessibility for housedust}

For the 12 slightly contaminated housedust samples, As-RBA ranged from $21.8 \pm 1.6$ to $85.6 \pm 7.2 \%$ with samples containing low Fe and high total organic carbon content having higher As-RBA (Li et al., 2014). Strong in vivo-in vitro correlations (IVIVC) were observed between As-RBA and As bioaccessibility for SBRC and DIN assays $\left(\mathrm{R}^{2}=0.63-0.85\right)$, but weaker ones for IVG and PBET assays $\left(\mathrm{R}^{2}=0.29-0.55\right)$.

For the $15 \mathrm{As}, \mathrm{Cd}$, and $\mathrm{Pb}$ co-contaminated housedust samples, As-, Cd-, and Pb-RBA was 7.64$37.0,20.3-94.3,7.21-52.1 \%$, averaging 21,52 , and $30 \%$, respectively. Analyses of relationship between
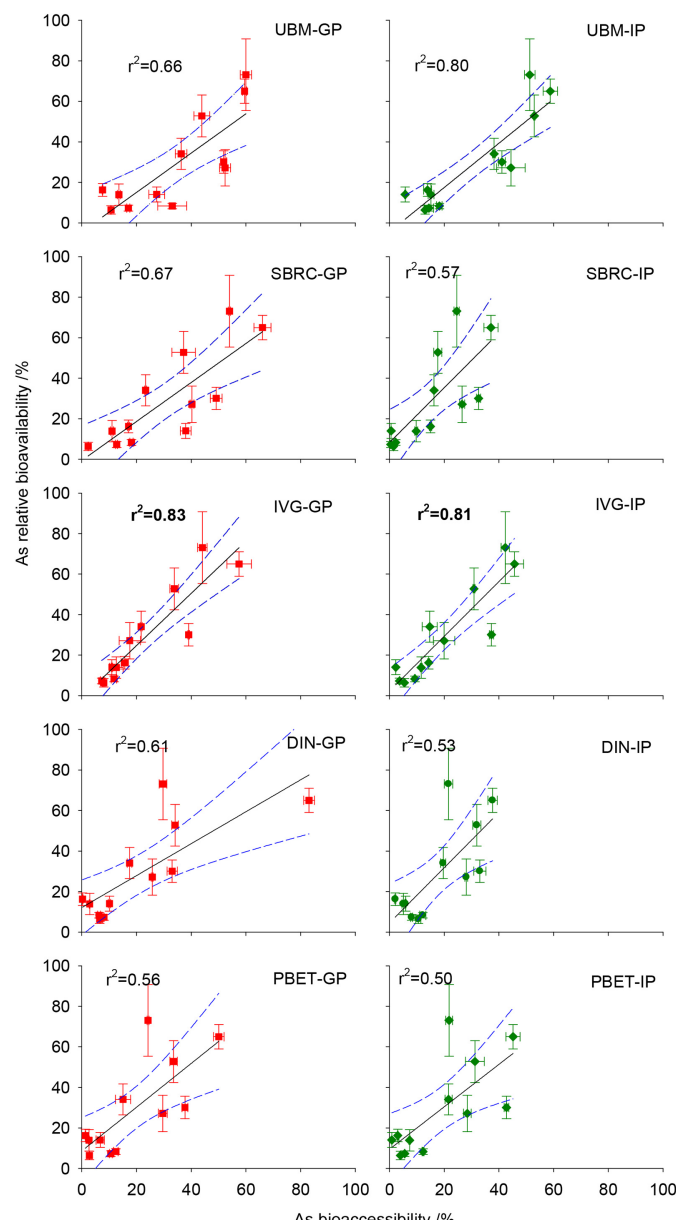

As bioaccessibility $1 \%$

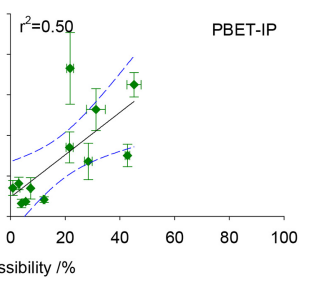

Figure 1. In vivo-in vitro correlations between As relative bioavailability (RBA) in 12 As-contaminated soils from China using a mouse model and As bioaccessibility determined using gastric (GP) and intestinal phases (IP) of five in vitro assays (UBM, SBRC, IVG, DIN, and PBET).

metal(loid) RBA and concentrations showed that $\mathrm{Pb}$ RBA decreased with increasing As concentration, while As-RBA decreased with increasing $\mathrm{Pb}$ and $\mathrm{Cd}$ concentration $\left(\mathrm{R}^{2}=0.62-0.72\right)$, suggesting that copresence of $\mathrm{As}$ and $\mathrm{Pb}$ decreased each other's RBA, while $\mathrm{Cd}$ reduced As-RBA.

By correlating metal(loid) RBA data with bioaccessibility data using the SBRC, PBET, and UBM assays, the strongest As in vivo-in vitro correlations were observed for the PBET assay $\left(\mathrm{R}^{2}=0.69\right)$.

\subsection{As-RBA in rice}

Following oral doses of individual As species to mice at low levels of As exposure (2.5-15 $\mu \mathrm{g}$ As per mouse) over a 7-d period, strong linear correlations $\left(R^{2}=0.99\right)$ were observed between As urinary excretion and cumulative As intake, suggesting the suitability and sensitivity of the mouse bioassay to measure 
As-RBA in rice. RBA in cooked rice ranged from $26.2 \pm 7.0 \%$ to $49.5 \pm 4.7 \%$ (averaging $39.9 \pm 8.3 \%$ ) for inorganic As. Calculation of inorganic As intake based on inorganic As concentration in rice led to an overestimate of As exposure by 2.02-3.67-fold compared to that calculated based on bioavailable inorganic As.

\section{CONCLUSIONS}

The results suggested that in vitro assays suitable to predict As-RBA varied with the target media. For accurate assessment of the health risk associated with incidental ingestion of soil and housedust and consumption of rice, it is important to consider As bioavailability.

\section{ACKNOWLEDGEMENTS}

This work was supported by National Natural Science Foundation of China (21507057; 41673101; 21637002; BK20150573).

\section{REFERENCES}

Hinwood, A.L., Sim, M.R., Jolley, D., de Klerk, N., Bastone, E.B., Gerostamoulos, J. \& Drummer, O.H. 2003. Hair and toenail arsenic concentrations of residents living in areas with high environmental arsenic concentrations. Environ. Health Perspect. 111(2): 187-193.

Juhasz, A.L., Smith, E., Weber, J., Rees, M., Rofe, A., Kuchel, T., Sansom, L. \& Naidu, R. 2006. In vivo assessment of arsenic bioavailability in rice and its significance for human health risk assessment. Environ. Health Perspect. 114(12): 1826-1831.

Li, G., Sun, G.X., Williams, P.N., Nunes, L. \& Zhu, Y.G. 2011. Inorganic arsenic in Chinese food and its cancer risk. Environ. Int. 37(7): 1219-1225.

Li, H.B., Li, J., Juhasz, A.L. \& Ma, L.Q. 2014. Correlation of in vivo relative bioavailability to in vitro bioaccessibility for arsenic in household dust from China and its implication for human exposure assessment. Environ. Sci. Technol. 48(23): 13652-13659.

Li, H.B., Zhao, D., Li, J., Li, S.W., Wang, N., Juhasz, A.L., Zhu, Y.G. \& Ma, L.Q. 2016a. Using the SBRC assay to predict lead relative bioavailability in urban soils: contaminant source and correlation model. Environ. Sci. Technol. 50(10), 4989-4996.
Li, H.B., Li, J., Zhao, D., Li, C., Wang, X.J., Sun, H.J., Juhasz, A.L. \& Ma, L.Q. 2017. Arsenic relative bioavailability in rice using a mouse arsenic urinary excretion bioassay and its application to assess human health risk. Environ. Sci. Technol. 51(8): 4689-4696.

Li, J., Li, C., Sun, H.J., Juhasz, A.L., Luo, J., Li, H.B. \& Ma, L.Q. 2016b. Arsenic relative bioavailability in contaminated soils: comparison of animal models, dosing schemes, and biological end points. Environ. Sci. Technol. 50(1): 453-461.

Liao, X.Y., Chen, T.B., Xie, H. \& Liu, Y.R. 2005. Soil As contamination and its risk assessment in areas near the industrial districts of Chenzhou City, Southern China. Environ. Int. 31(6): 791-798.

Ollson, C.J., Smith, E., Herde, P. \& Juhasz, A.L. 2017. Influence of sample matrix on the bioavailability of arsenic, cadmium and lead during co-contaminant exposure. Sci. Total Environ. 595: 660-665.

Ruby, M.V. \& Lowney, Y.W. 2012. Selective soil particle adherence to hands: implications for understanding oral exposure to soil contaminants. Environ. Sci. Technol. 46(23): 12759-12771.

Ruby, M.V., Schoof, R., Brattin, W., Goldade, M., Post, G., Harnois, M., Mosby, D.E., Casteel, S.W., Berti, W., Carpenter, M., Edwards, D., Cragin, D. \& Chappell, W. 1999. Advances in evaluating the oral bioavailability of inorganics in soil for use in human health risk assessment. Environ. Sci. Technol. 33(21): 3697-3705.

Torres-Escribano, S., Leal, M., Vélez, D. \& Montoro, R. 2008. Total and inorganic arsenic concentrations in rice sold in Spain, effect of cooking, and risk assessments. Environ. Sci. Technol. 42(10): 3867-3872.

Williams, P.N., Lei, M., Sun, G., Huang, Q., Lu, Y., Deacon, C., Meharg, A.A. \& Zhu, Y.G. 2009. Occurrence and partitioning of cadmium, arsenic and lead in mine impacted paddy rice: Hunan, China. Environ. Sci. Technol. 43(3): 637-642.

Zhu, Y.G., Sun, G.X., Lei, M., Teng, M., Liu, Y.X., Chen, N.C., Wang, L.H., Carey, A.M., Deacon, C., Raab, A., Meharg, A.A. \& Williams, P.N. 2008. High percentage inorganic arsenic content of mining impacted and nonimpacted Chinese rice. Environ. Sci. Technol. 42(13): 5008-5013.

Zhu, Z., Sun, G., Bi, X., Li, Z. \& Yu, G. 2013. Identification of trace metal pollution in urban dust from kindergartens using magnetic, geochemical and lead isotopic analyses. Atmos. Environ. 77: 9-15. 